\title{
Anastasia's Journeys: Two Voices in a Limited Space
}

NICOLA PULLAN

nastasia's Journeys was a temporary museum display which was
developed using the oral history of Katiusha Patryn, a Russian-
Ukrainian woman who migrated to Australia in 1949. ${ }^{1}$ The display was installed in the Australian History Museum at Macquarie University, Australia, in 2011, where it formed one of three presentations addressing immigration to Australia. This review examines some of the theoretical and practical issues which influenced the display audience, design and content. The discussion commences with an explanation of the museum's mission statement and the direction it gave to the display, followed by a summary of the historical context of the narrative. The design process through which the audio narrative became the core element is then considered, with a discussion of how objects and their placement were used to illustrate the complex and hidden social issues which influenced Katiusha's settlement in Australia. The final section 
identifies the attributes of the oral history narrative which made it suitable to become the primary voice of the display.

\section{THE MUSEUM}

The Australian History Museum is a small collecting institution which supports the university's academic programs by collecting primary source material for staff and students of the social sciences, and providing opportunities for museum studies students to research and display objects indicative of many aspects of twentieth-century social history. The museum promotes multi-disciplinary learning opportunities available within the museum context and supports teaching excellence and student engagement within the university. ${ }^{2}$ It also aims to provide museum access, enriched educational experiences and research resources to a wider audience comprising individuals, school students and members of community organisations. ${ }^{3}$ This exhibition was primarily designed for adolescents and adults drawn from university tutorial groups and academics from the Modern History and Museum Studies departments, secondary school students in Stages 5 and 6 (Years 9 to 12 ), university alumni and casual visitors.

The museum display space consists of a single gallery featuring a variety of permanent cabinet and audio-visual exhibitions. Themes addressed in these presentations include Indigenous Australians since 1788, Australia and the First World War, Australia and the British Empire, changing roles of women and the settlement of Greek and Indian immigrants in Australia. Anastasia's Journeys complemented the existing immigration displays as it presented the life-story and experiences behind the arrival of an East European participant in the post-World War Two Displaced Persons scheme, the most culturally diverse cohort of immigrants to arrive in Australia during the twentieth century.

On hearing the story of Katiusha Patryn's childhood, the Director of the museum suggested using the oral history recording as the foundation of a display which addressed one of the learning modules for Years 11 and 12 secondary students studying Modern History. The New South Wales Board of Studies Stage 6 Modern History syllabus section, National Studies: Key Features, includes the elective 'Russia and the Soviet Union 1917 to $1941^{\prime}$. This requires the students to study the political, economic and social policies of the former Union of Soviet Socialist Republics (USSR) under Stalin's Five Year Economic Plans and analyse the impact of collectivisation and industrialisation on the society, culture and economy. ${ }^{4}$ Katiusha's oral testimony was ideal as the core feature of 
such a presentation as her account of life in the Ukraine in the years following the 1917 Russian Revolution directly addressed the topic and also revealed how Stalin's policies initiated and shaped her personal experience of migration to Australia.

\section{HISTORICAL BACKGROUND}

In 1917, the provisional government which emerged from the Russian Revolution gave the population of the Russian Empire unprecedented social freedoms. This independence was soon curtailed after Lenin and the Bolsheviks destabilised the elected government. On taking power, they established the Communist Party, re-introduced conscription and a system of organised terror and initiated industrial, commercial and agricultural nationalisation. The resulting wide spread famine of 1921-22 forced Lenin to introduce the more liberal New Economic Policy in 1924.

Following Lenin's death, Stalin reinstated the previous high rate of collectivisation and, by 1929, had declared the start of the first Soviet Five Year Plan and his intention to 'liquidate the kulaks as a class'. Meaning 'tightfist', the new term, kulak, was used to describe peasants seen as challenging economic domination by the Communist Party. Liquidation was achieved through allocation of unattainable grain quotas followed by confiscation of all property, then deportation to unviable agricultural land or exile to concentration camps in inhospitable regions. These measures precipitated a second famine which lasted from 1929 to 1934 and caused the deaths of between eight and ten million people in the Ukraine and surrounding Russian provinces. In 1934, the remaining kulaks were declared to have been 'rehabilitated' and could apply for the internal passports necessary to obtain work. ${ }^{5}$

\section{KATIUSHA'S STORY}

Katiusha Patryn was born Anastasia Katarzyna Sharenko in autumn 1918 into a Ukrainian family living in a village close to the Russian border. In common with many survivors of Stalin's terror, Katiusha began her narrative with stories of civil war which she had heard in her family home. ${ }^{6}$ She then recounted incidents from her life with her parents after being designated 'daughter of kulaks' and sent with them into internal exile, becoming an orphan during the 1929-1934 famine, and growing up in poverty as a worker and then a driver on farms and agricultural collectives in Russia, eastern Ukraine and the Crimea.

When Germany invaded the USSR in 1941, she was conscripted into the Russian Army and, on the fall of Sevastopol in 1942, was deported to 
Germany to work as a slave labourer in a munitions factory. Her oral history then described escaping the factory, changing her name and being arrested and sent to work on a farm in the middle of Germany. Anastasia's narrative concluded with an account of her experiences while evading repatriation to the USSR after liberation in 1945, and finally being accepted for assisted emigration to Australia as a Displaced Person under the International Refugee Organisation re-settlement scheme. The social dislocation initiated by her family's designation as kulak and the many journeys which eventuated from this alienation became the theme of the display.

\section{DISPLAY DESIGN}

The new museum display communicated its message to the audience through verbal, non-verbal and symbolic forms of communication. ${ }^{7}$ Verbal communication consisted of two audio-tracks supplemented by text panels and labels. ${ }^{8}$ Photographs facilitated non-verbal understanding, while a cabinet display relied on the selection of objects and the symbolic use of space to communicate the effects of Stalin's policies and to provide a second and alternate 'voice'.

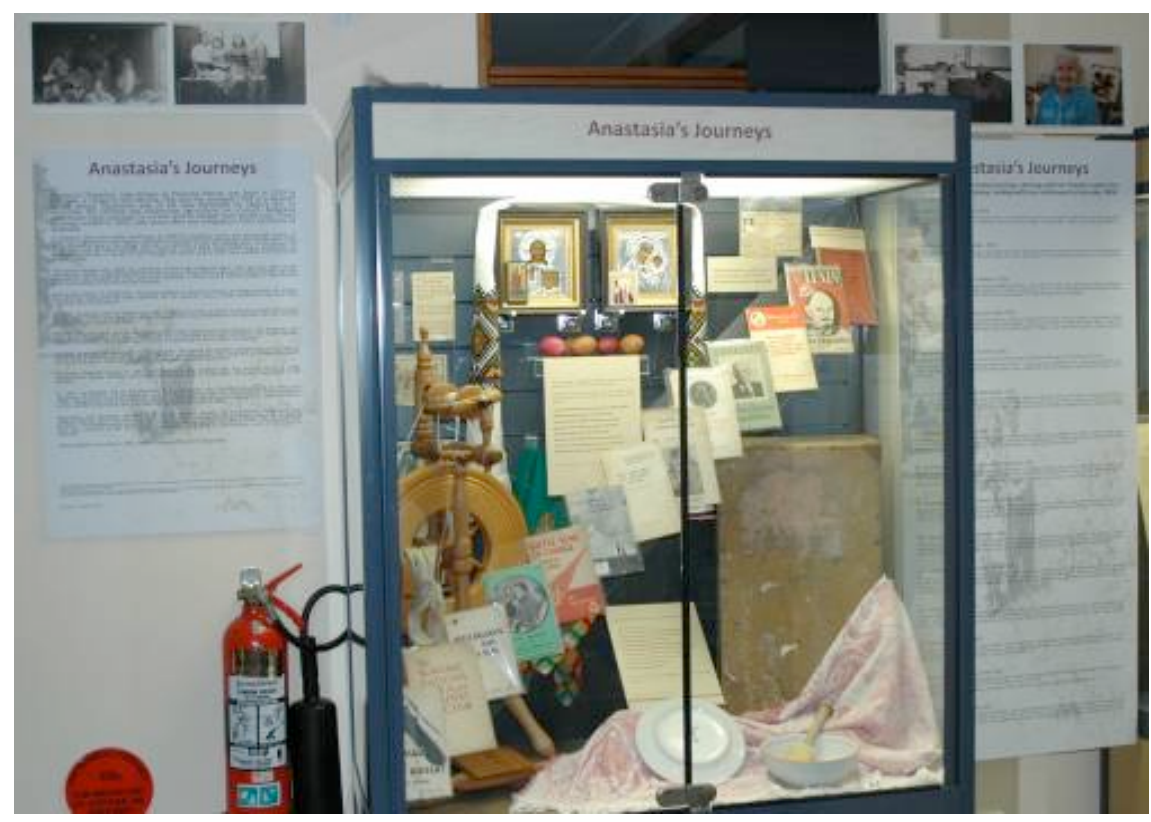

Figure 1 Anastasia's Journeys cabinet display with text panels and photographs (photograph the author)

Although a museum presentation is anticipated to be first and foremost a visual experience, Anastasia's Journeys featured audio tracks as the 
primary method of verbal communication. It was decided to give precedence to the aural qualities of Katiusha's testimony for two reasons. Firstly, the distinctive characteristics of an oral history are best preserved and conveyed when it is presented in a format which is as close to the aural version as possible. ${ }^{9}$ Secondly, video images with captions can distract the audience from the spoken words as they encourage the visitor to look or to read rather than to listen. ${ }^{10}$ Two supplementary wallmounted text panels comprised an introductory panel explaining the context of the narrative and a time-line panel which listed fifteen of Katiusha's journeys, each followed by a transcribed quotation describing her experience. Early exhibition designs allowed for one large context panel, with separate A4-sized text panels allotted for each journey. But this was not possible in the available space. Therefore, to reduce the bulk of the large blocks of text on each panel paragraphs were limited in size to a maximum of four lines and the timeline was widely spaced to mimic the appearance of individual panels. ${ }^{11}$

The one artefact to remain from Katiusha's life before the war was her Russian Driver's Licence. This absence of objects and images made it difficult to provide an opportunity to engage with the display through non-verbal communication. The licence and four images taken after the war were available for the display and these were complemented by a recent photograph taken during the interviews. In the official Russian photograph Katiusha looked directly at the camera and showed little emotion. But the post-war photographs revealed her reliance on her husband for emotional security, her excitement when packed on the train to Italy to embark for Australia, the pride she felt being able to celebrate family occasions in Sydney and her satisfaction with having an opportunity to share her story.

The objects in the display cabinet were placed symbolically to communicate the social dislocation caused by the introduction of Stalin's policies (see Figure 2). As Katiusha's story was divided by the imposition of Communist policies, the cabinet was divided into two sections by a diagonal line of Communist Party propaganda pamphlets selected from the museum's extensive collection of English-language Communist Party propaganda. Objects on the upper left of the cabinet represented the traditional peasant culture experienced before exile and were lent by members of the refugee community to replace the 'nowabsent' possessions mentioned by Katiusha in her narrative. Those on the lower right were collected by Katiusha after the war from various sites in Germany and consisted of the few domestic items she could 


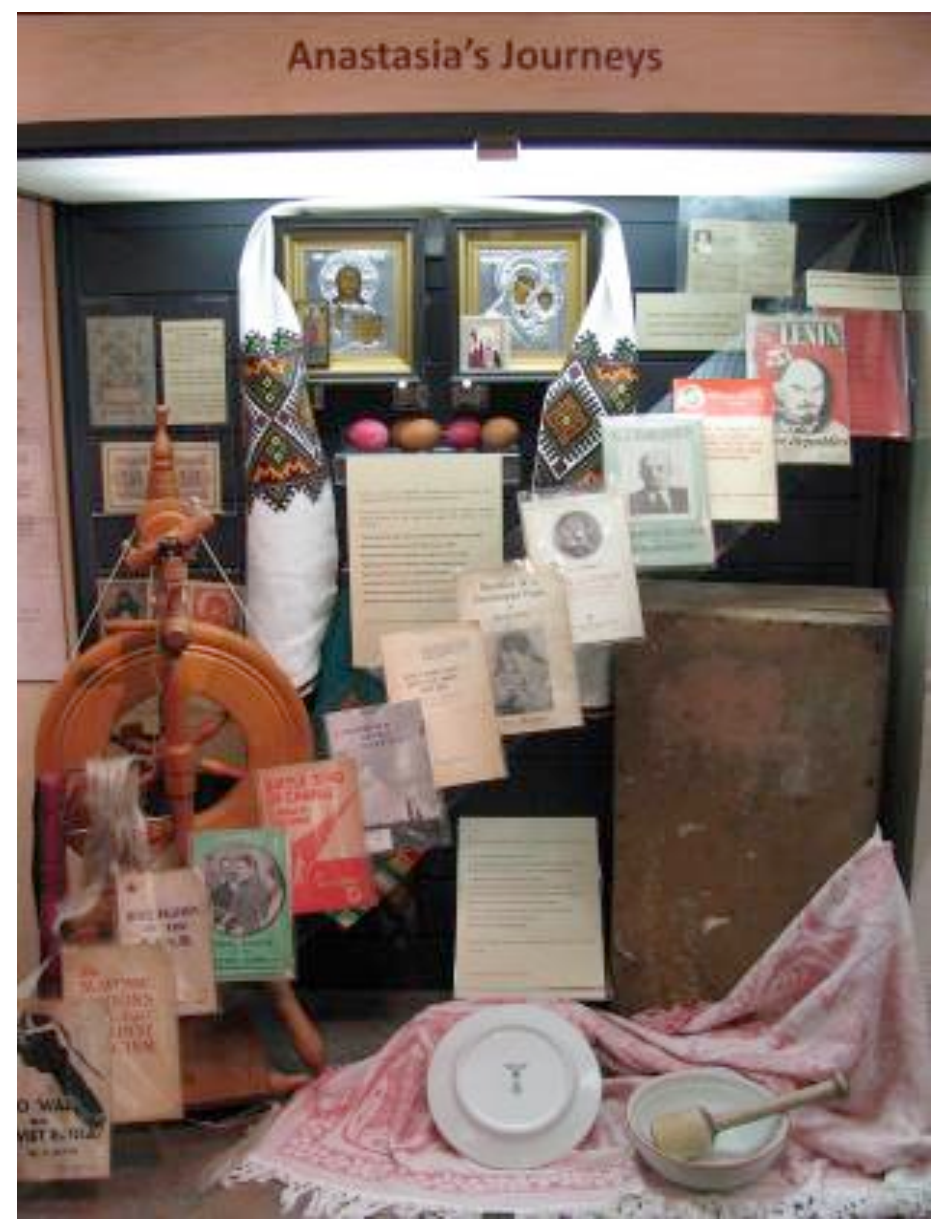

Figure 2 Display cabinet presenting traditional items, Communist Party pamphlets and objects brought from Germany (photograph the author)

obtain and the labelled wooden suitcase in which they were brought with her on the journey to Australia.

Katiusha's oral history recounted village life in the newlyCommunist Ukraine but an opposing voice was needed to balance the display. ${ }^{12}$ This was supplied by the pamphlets. These booklets promoted the official view of the Soviet government under Stalin and were published from the mid 1920s to the 1950s by the Party-sponsored Foreign Languages Publishing House in Moscow, London and Sydney. Bearing titles such as Communism Brings Happiness, Qualities of a Communist Party and The Legal Rights of the Soviet Family, they were published to persuade readers in democratic countries that Soviet policies provided a way of life preferable to that experienced under capitalism. While the publications promoted the supposed advantages of 
life under Soviet hegemony, the oral history provided a direct experience of the negative social impacts of Stalinist totalitarianism. ${ }^{13}$

\section{CONNECTING With AN AUdIENCE THROUgh ORAL HISTORY}

Gaynor Kavanagh emphasised that history which captures the audience interest and initiates an emotional experience 'leads to the motivation to learn something'. A successful historical presentation needs to build an emotional connection between the objects, images, or oral testimony which engages with the past and the life experiences of the visitor or audience in the present. ${ }^{14}$ Katiusha's oral narrative demonstrated four attributes which initiated such a connection. ${ }^{15}$

Firstly, Katiusha's story was a personal account of extreme and dramatic events and her narrative style evoked very powerful images which caught the visitor's attention and held their interest. ${ }^{16}$ Katiusha began her story by telling the listener that she was 'born in the Revolution'. From the first sentence, the audience was transported back to 1917, then given the opportunity to experience first-hand many largely unrecorded events in twentieth-century Russian history. Katiusha told of the farmers' flight into the fields caused by marauding bands of guerrilla soldiers, the requisitioning of their entire harvest, the death of her family from starvation, trying to find work with false papers and bombardment and invasion by the German army. She became the village soldiers saying: 'We don't want, we don't want to fight!', and one of the women calling: 'Coming... coming... coming the Revolutionaries!' Her use of reported speech gave the recount an immediacy which placed the audience within the scene being described and enabled greater identification with the social dislocation which was occurring. ${ }^{17}$

Secondly, the narrative was a first-hand account of emotional personal experiences which created intimacy and encouraged empathy. ${ }^{18}$ Jill Cassidy emphasises that 'it is emotions that oral history is so well suited to highlight' ${ }^{19}$ The memories which Katiusha holds and recounts are those which have made a deep emotional impression. She told of her life within the family: being loved by her father; cared for by her mother, aunt and grandmother; teased by her brother; and teasing her sister. She recounted the excitement playing in the snow with her brother; the joy shared with other children when racing floating grass 'ducks' down the melting snow rivulets 'we had beautiful time!'; and the comfort when her grandmother taught her to cross-stitch: 'You come to me, I'll show you how to do these crosses'.$^{20}$ She recalled in great detail her mother becoming distraught as Katiusha's first embroidery is confiscated and sold; her confusion and shame at being designated kulak and exiled from 
the village; her sense of loss when she wakes in exile to realise her mother has died of starvation while she slept, 'and when I wake up mother - it's gone'; and her desperation when touching the feet of her dead father 'and try to wake him up'. ${ }^{21}$ Katiusha's inclusion of her emotions created a shared experience with the audience and fostered audience connections with the events being recounted.

Thirdly, an oral history useful for an effective museum display needs to give insight into the thoughts and beliefs of the narrator without tending to 'overstate individual agency and obscure the workings of political and cultural power', and to avoid the inherent danger of depoliticising events when presenting personal viewpoints. ${ }^{22}$ Katiusha's oral history included events which she placed in context and thus allowed the display to include the external political and social forces which helped shape her identity. ${ }^{23}$ The story was recounted as an individual experience of the effects of political domination rather than a 'direct window on the... meaning of past experience'. And she acknowledged the role of the Soviet state and Nazi Germany in shaping her history. ${ }^{24}$

Katiusha's narrative included many references to Soviet authority under Stalin, in particular her anger and frustration at the impotence of the people when confronted by property confiscation and exile. When her family needed help she recalled that 'we had lot of neighbours, they would like to take me to their house, until they're ready for a small child, but they're scared because they shouldn't - kulaks shouldn't do for kulaks anything, and it was stupid'. She also remarked that although she didn't like the sleeping arrangements while staying with these friends, 'I couldn't say - because I am "kulak"'. As the display needed to address the social and cultural impact of collectivisation and industrialisation on Soviet Russia, this oral testimony filled an important role in providing an individual's responses to the prevailing situation while explaining the political context. ${ }^{25}$

Finally, incidents and events recounted by Katiusha placed these experiences in a chronological and political framework which guided the listener into taking an active interpretative role and encouraged exploration of fresh perspectives on documented history. ${ }^{26}$ Katiusha mentions her father and other Ukrainian soldiers who were conscripted to fight for Tsarist Russia in the First World War saying: 'Why, why do we fight?' and deciding to return home; her father hiding in the fields to avoid recruitment 'or else we would be starved and died if nobody working'; and the revolutionaries being 'not very smart' when they came to the village. Such comments included in the audio tracks allowed the 
audience the space to question previously accepted interpretations of Russian involvement in the First World War and to critically analyse contradictory versions of the narrative surrounding the Russian Revolution and the subsequent civil war.

\section{CONCLUSION}

Gaynor Kavanagh highlighted the need for an exhibition to use the connection and sense of identification engendered by an oral history narrative to act as the 'rope' for the audience to build a 'web' which 'allows and indeed encourages lateral thinking and logical connection' by the audience. The 'rope' provided by Katiusha's narrative allowed the audience to construct a 'web' connecting her experiences in the USSR with her emigration from Germany to Australia after the war. ${ }^{27}$ At a time when Stalinist Communism was openly supported by many socially conscious citizens of Western nations, Stalin instituted policies of 'dekulakisation' in the Ukraine and surrounding areas of Russia. ${ }^{28}$ These policies dislocated Katiusha from the rich cultural traditions of her Ukrainian forebears..$^{29}$ Forced to work for the benefit of the Soviet state, for the next twelve years Katiusha's life consisted of constant journeys within Russia and the Ukraine in search of a secure existence. After the 1942 German invasion of the Crimea, her life was further destabilised as she was deported to labour in Nazi Germany. ${ }^{30}$ On her liberation by the Allied powers in Germany in 1945, Katiusha had to choose between two possible futures. She could either allow herself to be forcibly repatriated to the USSR to live once more under Stalin's authoritarian regime, where she again would have no control over her life. Or she could apply to migrate to a democratic country actively recruiting workers. Katiusha chose to undertake yet another journey. She and her husband migrated to Australia in 1949.

The use of two voices in the display provided a framework to support further audience enquiry into the political, economic and social policies of the Soviet states under Stalin's Five Year Economic Plans. Ludmilla Jordanova has observed that the relationship between academic and public history should encourage contemplation and thought, and not interpret the past as the purveyor of a 'clear, unambiguous lesson'. It, therefore, 'should raise awkward questions, unsettle received views and the designers should realise that the public can appreciate these points' ${ }^{31}$ While the Communist Party publications promoted the supposed advantages of life under Soviet hegemony, the oral history used direct experience to encourage audience connection with the social impact of these Soviet policies. ${ }^{32}$ In presenting one 
person's experiences of the impact of Stalinist policies, Anastasia's Journeys allowed the audience to connect the reality of these policies with the decision of many former residents of the USSR to leave Europe after the Second World War. As such hidden and complex social relationships do not exist in an immediately transparent and accessible way, the challenge for the display was to enable them to become more evident and still provide an opportunity for learning as an activity, rather than the passivity of being taught.

\section{ENDNOTES}

${ }^{1}$ Katiusha Patryn_1, interviewed by the author, 9 February 2011, recording in author's possession. A detailed account of Anastasia's experiences can be found at Pullan, N. 'Anastasia's Journey' (Online), e-mus-ine, vol 8, 2011. Available: http:/ / amusine.typepad.com/journeys/ anastasias-journey.html (Accessed 29 Oct 2013).

${ }^{2}$ Australian History Museum, Strategic Plan 2008-2010, unpublished, Australian History Museum Management Committee, Macquarie University, 2008, p2.

${ }^{3}$ ibid.

${ }^{4}$ Board of Studies 2009, 'Modern History Stage 6 Syllabus'. Available: www.boardofstudies.nsw.edu.au (Accessed 17 Mar 2011), p35.

5 J. N. Westwood, Endurance and Endeavour: Russian History 1812-1971, Oxford University Press, London, 1973, pp228; 247; 272; 277-8; 292; 296; 297; 299 (ftn 16) and Marco Carunnyk, 'Malcolm Muggeridge on Stalin's famine: "deliberate" and "diabolical" starvation', in The Ukrainian Weekly (ed), The Great Famine in Ukraine: The Unknown Holocaust, Jersey City, 1983.

${ }^{6}$ Orlando Figes 'Private lives in Stalin's Russia: Family narratives, memory and oral history', History Workshop Journal, vol 65, no 1, 2008, p123.

${ }^{7}$ Gaynor Kavanagh, 'Objects as evidence', in Gaynor Kavanagh (ed), History Curatorship, Leicester University Press, Leicester, 1990, p107.

${ }^{8}$ ibid, pp108;109.

${ }^{9}$ Tim Bowden, 'Let's not throw the baby out with the bathwater', Oral History Association of Australia Journal, vol 27, 2005, p63.

${ }^{10}$ A similar decision was recounted in Anna Green, 'The exhibition that speaks for itself', in Robert Perks and Alistair Thomson (eds), The Oral History Reader, Routledge, New York, 1998, p449.

${ }^{11}$ Peta Landman, Museum Methods: A Practical Guide for Managing Small Museums and Galleries, Museums Australia, Canberra, 2002, 4.1-4.9.

${ }^{12}$ Paula Hamilton, Creating, using and preserving oral histories: issues and challenges, unpublished conference paper, New Ways with Oral History: The Use and Abuse of Oral History, Museums and Galleries NSW, Sydney, 2011.

${ }^{13}$ Brian Crozier, 'What was it like: a perspective on history in museums', (Online), 2009. Available: http: / / www.nma.gov.au / audio/transcripts / collections09/NMA_Crozier_200903 27.html.(Accessed 14 Jan 2012), p3.

${ }^{14}$ Gaynor Kavanagh, 'Making histories, making memories', in Gaynor Kavanagh (ed), Making Histories in Museums, Leicester University Press, London, 1996, pp13; 11.

${ }^{15}$ Jo Blatti, 'Public history and oral history', Journal of American History, vol 77, 1990, pp615; 620.

${ }^{16}$ ibid, p618; Kavanagh, 'Making histories, making memories', p12; Christine Finnemore, 'Voices of identity: Oral history in South Australia's migration museum', Oral History Association of Australia Journal, vol 16, 1994, p102. 
${ }^{17}$ Tony Taylor, 'Trying to connect: Moving from bad history to historical literacy in schools', Australian Cultural History, no 23, 2003, p186.

${ }^{18}$ Alistair Thomson, 'Moving Stories: oral history and migration studies', Oral History, vol 27, no 1, 1999, p35; Kavanagh, 'Making histories, making memories', p12.

${ }_{19}$ Jill Cassidy 'Migration memories on multi-media at a museum', Oral History Association of Australia Journal, vol.25, 2003, p91.

${ }^{20}$ Katiusha Patryn_1, op cit.

${ }^{21}$ Katiusha Patryn_2 , interviewed by the author, 9 February 2011, recording in author's possession.

${ }^{22}$ Linda Shopes, 'Making sense of oral history' (Online). Available: http:/ / historymatters.gmu.edu (Accessed 10 Dec 2010), pp. 3, 5; Michael Frisch, A Shared Authority: Essays on the Craft and Meaning of Oral and Public History, State University of New York Press, Albany, 1990, p162.

${ }^{23}$ Blatti, op cit, p617.

${ }^{24}$ Frisch, op cit, p160.

${ }^{25}$ Board of Studies, op cit, p. 35; Shopes, op cit, p5.

${ }^{26}$ Blatti, op cit, pp616, 617; Richard West, 'American museums in the 21st century', Humanities Research, vol ix, no 1, 2002, p58; Kavanagh, 'Making histories, making memories', p12.

${ }^{27}$ Kavanagh, 'Making histories, making memories', p12.

${ }^{28}$ Carunnyk, op cit, no pagination.

${ }^{29}$ For corroboration of Katiusha Patryn's experiences in the USSR see Miron Dolot, Who Killed Them and Why?, Harvard University Ukrainian Studies Fund, Cambridge, Mass, 1984; Oksana Procyk, Leonid Heretz and James E. Mace (eds), Famine in the Soviet Ukraine 1932-1933, Harvard College Library, Cambridge, Mass, 1986; Roman Serbyn and Bohdan Krawchenko (eds), Famine in Ukraine 1932-1933, Canadian Institute of Ukrainian Studies, Edmonton, 1986; Ukrainian Weekly (ed), The Great Famine in Ukraine: The Unknown Holocaust, Ukrainian National Association, Jersey City, 1983.

${ }^{30}$ For a discussion of the use of Ukrainian and Russian labour in Nazi Germany see Edward L. Homze, Foreign Labour in Nazi Germany, Princeton University Press, Princeton N.J., 1967, pp80-87.

${ }^{31}$ Ludmilla Jordanova, History in Practice, Arnold, London, 2000, p171.

${ }^{32}$ Crozier, op cit, p3. 